\title{
PERANAN PACKAGING DALAM MENINGKATKAN HASIL PRODUKSI TERHADAP KONSUMEN
}

\author{
Syukrianti Mukhtar, Muchammad Nurif
}

\begin{abstract}
Abstrak
Kebutuhan masyarakat sekarang ini semakin meningkat dalam berbagai hal. Peluang seperti ini bagi seorang Technopreneurship merupakan peluang yang sangat baik untuk mengembangkan usaha dan dapat juga menciptakan usaha baru yang mengembangkan perusahaannya. Berangkat dari perihal ini seorang Technopreneurship harus menganalisa pasar, mendesain, dan lain-lain, agar peluang-peluang ini terisi yang tidak kalah penting disamping kesiapan daya tarik dari berbagai hal produk, yang menjadi pemikat konsumen adanya beraneka macam kemasan atau packaging dapat meletakkan dan menyelemat bahkan menyimpan produk yang di produksi, sehingga menjadi daya pikat tersendiri bagi masyarakat sekarang ini.
\end{abstract}

Kata kunci : Produk, Packaging, Konsumen

Kemasan atau packaging adalah suatu wadah yang menempati suatu barang agar aman, menarik, mempunyai daya pikat dari seorang yang ingin membeli suatu produk. Dapat juga menjadi media komunikasi antara produsen dengan calom konsumen, sehingga didalam desain kemasan tercantum informasi-informasi yang harus diketahui oleh calon konsumen, agar calon konsumen merasa tidak asing dengan produk yang di kemas. Semakin lengkap informasi yang tertera dikemasan persepsi dari calon pembeli semakin tau dan meyakinkan terhadap produk yang di jual yang akan dibelinya.

Pada mulanya fungsi kemasan hanya sebatas untuk melindungi barang dan mempermudah waktu membawanya agar tidak rusak sampai tujuan. Dengan ada kemasan, konsumen mendapat layanan dalam menyelamatkan barang yang dibeli dan mempunyai jaminan yang ada kepuasan tersendiri dari barang produk yang akan menjadi milik dirinya, yang akhirnya terselamatkan dari hal yang tidak diharapkan selama di perjalanan sampai tujuan.

Seiring dengan perkembangan jaman yang semakin kompleks barulah terjadi penambahan nilai-nilai fungsional dan peranan kemasan dalam pemasaran mulai di akui sebagai satu kekuatan utama dalam persaingan pasar. 


\section{PERANAN PACKAGING}

Peranan kemasan lambat laun semakin memikat para konsumer ini dirasakan mulai kelihatan tahun 1950-an, saat ini terutama di Indonesia banyak bermunculan toko swalayan, dimana kemasan harus "dapat menjual" produk di rak-rak toko. Tetapi disaat itupun kemasan hanya berfungsi sekedar memberikan informasi kepada konsumen tentang apa isi dalam kandungan didalam kemasan tersebut.

Baru pada tahun 1980-an dimana persaingan dalam dunia usaha semakin tajam dan kalangan produsen saling berlomba untuk merebut perhatian calon konsumen, bentuk dan model kemasan dirasakan sangat penting peranannya dalam strategi pemasaran. Disitulah kemasan harus mempu menarik perhatian, menggambarkan keistimewaan produk untuk menghimbau agar calon konsumen tertarik. Pada saat inilah kemasan mengambil alih tugas penjualan pada saat jual beli terjadi.

Di masa era globalisasi sekarang ini packaging semakin meningkat perkembangannya, misal untuk membawa produk-produk yang bernilai kapasitas besar dan memiliki produk bernilai teknologi tinggi seperti : alat berat, mobil, perangkat peralatan bernilai elektronik. Packagingnya pun memiliki nilai tinggi demi menyelamatkan produk tidak rusak, sampai perihal limbah-limbah packaging pun bisa dimanfaatkan untuk produk yang mempunyai nilai tinggi dan seni tinggi yang tepat guna, banyak diminati oleh para calon konsumen.

Kemasan dalam Kamus Besar Bahasa Indonesia (2000:537) berarti hasil mengemas/bungkus pelindung barang dagangan. Kemasan atau packaging adalah ilmu, seni dan teknologi yang bertujuan untuk melindungi sebuah produk saat akan dikirim, disimpan atau dijajakan atau bisa juga suatu proses produksi yang bertujuan untuk mengemas. Menurut Widiatmoko (2007:20) bahwa secara hakiki packaging merupakan upaya manusia untuk mengumpulkan sesuatu yang berantakan kedalam suatu wadah serta melindunginya dari gangguan cuaca.

Menurut Marianne Rosner Klimchuk dan Sandra A. Krasnova (2006) menyatakan kata "kemasan" mengimplementasikan hasil akhir dari proses mengemas. Menurut Cenadi (2000) menyatakan kemasan dapat didefinisikan 
sebagai kegiatan merancang dan memproduksi wadah atau bungkus suatu produk. Kemasan meliputi tiga hal yaitu :

1. Kemasan memenuhi syarat keamanan dan manfaat. Kemasan melindungi produk dalam perjalanannya dari produsen ke konsumen. produk yang dikemas biasanya lebih bersih, menarik dan material yang tahan terhadap kerusakan yang disebabkan oleh cuaca dan kondisi perjalanan.

2. Kemasan dapat melaksanakan program pemasaran. Melalui kemasan identifikasi produk menjadi lebih efektif dan dengan sendirinya mencegah pertukaran oleh produk lain.

3. Kemasan merupakan suatu cara untuk meningkatkan penghasilan atau omset perusahaan. Oleh karena itu perusahaan harus membuat kemasan semenarik mungkin. Dengan kemasan yang menarik akan memikat perhatian konsumen untuk membeli produk. Selain itu, kemasan juga mengurangi kemungkinan kerusakan produk dan memberikan kemudahan dalam pengiriman.

Menurut Marianne Rosner Klimchuk dan Sandra A. Krasnova (2006) menyatakan mengemas adalah tindakan membungkus atau menutup suatu barang. Definisi lain yang diungkapkan oleh Kothler dan Amstrong (2007) adalah kegiatan merancang desain dan memproduksi wadah atau pembungkus produk.

Menurut Marianne Rosner Klimchuk dan Sandra A. Krasovec (2006) menyatakan desain kemasan adalah bisnis kreatif yang mengkaitkan bentuk, struktur, material, warna, citra, tipologi dan elemen-elemen desain dengan informasi produk agar produk dapat dipasarkan . Desain kemasan berlaku untuk membungkus, melindungi, mengirim, mengelarkan, menyimpan, mengidentifikasi dan membedakan sebuah produk dipasar.

Sedangkan menurut Bhakti (2001) dalam Natadjaja (2002) menyatakan kemasan seharusnya merupakan kesan singkat dari citra produk yang ingin disampaikan oleh pabrik, dan kemasan tersebut haruslah terpadu dengan fungsi produk. Desain kemasan memerlukan banyak pemikiran dan tentu saja bukansuatu hal yang mudah. Yang paling penting, kemasan menggambarkan merk di mata konsumen, dan bila orang mengingat merk tersebut mereka menghayalkan kemasan tersebut, dalam hal seperti ini sampai dengan yang menghasilkan penjualan. 


\section{FUNGSI KEMASAN}

Direktorat Jenderal Pengelolahan dan Pemasaran Hasil Pertanian Kementrian Pertanian Republik Indonesia (2012) menginformasikan secara umum fungsi kemasan adalah:

1. Melindungi dan mengawetkan produk, seperti melindungi dari sinar ultraviolet, panas, kelembaban udara, benturan serta kontaminasi kotoran dan mikroba yang dapat merusak dan menurunkan mutu produk.

2. Sebagai identitas produk, dalam hal ini kemasan dapat digunakan sebagai alat komunikasi dan informasi kepada konsumen melalui merk yang tertera pada kemasan.

3. Meningkatkan efisiensi, seperti memudahkan proses penghitungan pengiriman dan penyimpanan produk.

Rahmatillayev Nurnatjon menyatakan kemasan produk adalah bagian penting keamanan produk makanan. karena, kemasan yang baik melindungi produk dari kerugian dan kerusakan sementara menjaga kualitas produk di dalamnya, yang bisa di pengaruhi oleh perubahan iklim, penyimpanan dan penanganan yang tidak benar. Ini adalah penggunaan dan tujuan primer dari kemasan yang lebih focus pada menyampaikan kualitas keamanan.

Natadjaja (2002) menyatakan bahwa fungsi kemasan lebih dari fungsi teknis. Kemasan justru harus berfungsi sebagai "Ambasador" atau "Duta Besar" yang mewakili total konsep suatu produk atau jasa.

Menurut Kotler dan Amstrong (2001) sudah menjadi kebiasaan lama, fungsi utama pembungkus adalah memuat dan melindungi produk. Saat ini, banyak factor yang membuat kemasan menjadi alat pemasaran yang penting. Persaingan meningkat dan berlimpah ruahnya produk di rak took eceran mengharuskan kemasan menampilkan berbagai tugas pemasaran yaitu, mulai dari menarik perhatian, menjelaskan produk, hingga membuat penjualan

Kemasan yang baik adalah kemasan yang mampu melindungi isi produk dengan maksimal dan mampu menyediakan informasi lengkap tentang produk bagi konsumen. Informasi produk sangat penting bagi konsumen, jika konsumen masih 
salah menggunakan produk karena informasi tidak tertera jelas pada kemasan, maka tindakan hukum perlu dilakukan karena ada undang-undang Republik Indonesia Nomor 8 Tahun 1999 Tentang Perlindungan Konsumen (Dikti).

\section{LABEL}

Menurut Marianne Rosner Klimchuk dan Sandra A. Krasovec (2006) label biasanya terbuat dari kertas atau film plastic dengan atau tanpa tambahan perekat, label dapat mencakup keseluruhan kemasan atau hanya setempat saja. Satu bentuk kemasan fleksibel adalah film yang dapat disusut regangkan yang digunakan sebagai label. Material tersebut ketika diaplikasikan pada kemasan dengan pemanasan, meregang mengikuti bentuk kontur benda yang dilapisinya. Kontainer plastic, botol kaca, kaleng dan struktur kaku lainnya dapat dilapisi dengan kemasan fleksibel ini.

Label dapat bervariasi mulai dari tanda pengenal produk yang sederhana hingga grafik rumit yang merupakan bagian dari kemasan. Label menampilkan beberapa fungsi. Pada tingkatan paling akhir, label mengidentifikasi produk atau merk. Label juga menjelaskan beberapa hal mengenai produk, siapa yang membuatnya, dimana dibuat, pakan dibuat, isinya, bagaimana produk tersebut digunakan dan bagaimana menggunakannya dengan aman.

\section{DESAIN KEMASAN SEBAGAI MEDIA KOMUNIKASI DAN INFORMASI}

Desain kemasan selain untuk memberikan daya tarik dari sisi visual tentunya desain kemasan harus menjadi media komunikasi antar produsen dengan calon konsumen, sehingga dalam desain kemasan harus tercantum informasi-informasi yang harus diketahui oleh calon konsumen sehingga calon konsumen merasa tidak asing dengan produk yang dikemas. Perlu diketahui juga bahwa semakin lengkap informasi yang tercantum dalam kemasan semakin pula memberikan persepsi yang lebih baik kepada produk.

Yang harus dicantumkan dalam desain kemasan sebagai berikut:

- Nama Produk/Nama Makanan

- Komposisi/Daftar Ingredients

- Isi/Netto 
- Nama dan Alamat Pabrik/Importer

- Nomor BPOM/PIRT

- Info Halal

- Kode Produksi

- Tanggal Kadaluarsa

- Petunjuk cara penyimpanan

- Petunjuk cara penggunaan

- Nilai Gizi

\section{FUNGSI KEMASAN}

Hermawan Kartajaya, seorang pakar di bidang pemasaran mengatakan bahwa teknologi telah membuat packaging berubah fungsi, dulu orang bilang "Packaging protects what it sells (Kemasan melindungi apa yang dijual)". Sekarang, "Packaging sells what it protects (Kemasan menjual apa yang dilindungi)". Dengan kata lain, kemasan bukan lagi sebagai pelindung atau wadah tetapi harus dapat menjual produk yang dikemasnya. Perkembangan fungsional kemasan tidak hanya berhenti sampai di situ saja. Sekarang ini kemasan sudah berfungsi sebagai media komunikasi. Misalnya pada kemasan susu atau makanan bayi seringkali dibubuhi nomor telepon toll-free atau bebas pulsa. Nomor ini bisa dihubungi oleh konsumen tidak hanya untuk complain, tetapi juga sebagai pusat informasi untuk bertanya tentang segala hal yang berhubungan dengan produk tersebut. Kemasan juga dapat berfungsi untuk mengkonsumsikan suatu citra tertentu. Contohnya, produk-produk makanan Jepang. Orang Jepang dikenal paling pintar membuat kemasan yang bagus. Permen Jepang sering kali lebih enak dilihat dari pada rasanya. Mereka berani menggunakan bahan-bahan mahal untuk membungkus produk yang dijual. Walaupun tidak ada pesan apa-apa yang ditulis pada bungkus tersebut, tapi kemasannya mengkomunikasikan suatu citra yang baik. Semua produk yang dijual di pasar swalayan harus benar-benar direncanakan kemasannya dengan baik. Karena produk dalam kategori yang sama akan diletakkan pada rak yang sama. Jika produsen ingin meluncurkan suatu produk baru, salah satu tugas yang penting adalah membuat kemasannya stands out, lain daripada yang lain dan unik. Kalau tidak 
terkesan berbeda dengan produk lain, maka produk baru itu akan "tenggelam". Sebelum mencoba isinya, konsumen akan menangkap kesan yang dikomuniksikan oleh kemasan. Dengan demikian kemasan produk baru tersebut harus mampu “beradu” dengan kemasan produk-produk lainnya (Hermawan Kertajaya, 1996).

\section{FAKTOR-FAKTOR DESAIN KEMASAN}

Kemasan yang baik dan akan digunakan semaksimal mungkin dalam pasar harus mempertimbangkan dan dapat menampilkan beberapa factor, antara lain sebagai berikut.

\section{Faktor Pengamanan}

Kemasan harus melindungi produk terhadap berbagai kemungkinan yang dapat menjadi penyebab timbulnya kerusakan barang, misalnya: cuaca, sinar matahari, jatuh, tumpukan, kuman, serangga dan lain-lain. Contohnya, kemasan biscuit yang dapat ditutup kembali agar kerenyahannya tahan lama.

\section{Faktor Ekonomi}

Perhitungan biaya produksi yang efektif termasuk pemilihan bahan, sehingga biaya tidak melebihi proporsi manfaatnya. Contohnya, produk-produk refill atau isi ulang, produk-produk susu atau makanan bayi dalam karton, dan lain-lain.

\section{Faktor Pendistribusian}

Kemasan harus mudah didistribusikan dari pabrik ke distributor atau pengecer sampai ke tangan konsumen. Ditingkat distributor, kemudahan penyimpanan dan pemajangan perlu dipertimbangkan. Bentuk dan ukuran kemasan harus direncanakan dan dirancang sedemikian rupa sehingga tidak sampai menyulitkan peletakan di rak atau tempat pemajangan.

\section{Faktor Komunikasi}

Sebagai media komunikasi kemasan menerangkan dan mencerminkan produk, citra merk, dan juga bagian dari produksi dengan pertimbangan mudah dilihat, dipahami dan diingat. Misalnya, karena bentuk kemasan yang aneh sehingga produk tidak dapat "diberdirikan", harus diletakkan pada 
posisi "tidur" sehingga ada tulisan yang tidak dapat terbaca dengna baik, maka fungsi kemasan sebagai media komunikasi sudah gagal.

\section{Faktor Ergonomi}

Pertimbangan agar kemasan mudah dibawa atau dipegang, dibuka dan mudah diambil sangatlah penting. Pertimbangan ini selain mempengaruhi bentuk dari kemasan itu sendiri juga mempengaruhi kenyamanan pemakai produk atau konsumen. Contohnya, bentuk botol minyak goring Tropical yang pada bagian tengahnya diberi cekungan dan tekstur agar mudah dipegang dan tidak licin bila tangan pemakainya terkena minyak.

\section{Faktor Estetika}

Keindahan pada kemasan merupakan daya tarik visual yang mencakup pertimbangan penggunaan warna, bentuk, merk atau logo, ilustrasi, huruf, tata letak atau layout, dan mascot. Tujuannya adalah untuk mencapai mutu daya tarik visual secara optimal.

\section{Faktor Identitas}

Secara keseluruhan kemasan harus berbeda dengan kemasan lain, memiliki identitas produk agar mudah dikenali dan dibedakan dengan produk-produk yang lain.

\section{Faktor Promosi}

Kemasan mempunyai peranan penting dalam bidang promosi, dalam hal ini kemasan berfungsi sebagai silent sales person. Peningkatan kemasan dapat efektif untuk menarik perhatian konsumen-konsumen baru.

\section{Faktor Lingkungan}

Kita hidup di dalam era industry dan masyarakat yang berpikiran kritis. Dalam situasi dan kondisi seperti ini, masalah lingkungan tidak dapat terlepas dari pantauan kita. Trend dalam masyarakat kita akhir-akhir ini adalah kekhawatiran mengenai polusi, salah satunya pembuangan sampah. Salah satunya yang pernah menjadi topic hangat adalah styrofoom. Pada tahun 1990 organisasi-organisasi lingkungan hidup berhasil menekan perusahaan Mc Donald untuk mendaur ulang kemasan-kemasan mereka. Sekarang ini banyak perusahaan yang menggunakan kemasan-kemasan yang 
ramah lingkungan (environmentally friendly), dapat didaur ulang (recyclable) atau dapat dipakai ulang (reuseable).

\section{RAGAM KEMASAN}

Ada beberapa bahan yang digunakan dalam pembuatan kemasan, diantaranya adalah kemasan dari kertas, kemasan dari kayu, dan kemasan dari plastic.

\section{a. Kemasan Kertas}

Kemasan kertas merupakan kemasan fleksibel yang pertama sebelum ditemukannya plastic dan aluminium foil. Saat ini kemasan kertas masih banyak digunakan dan mampu bersaing dengan kemasan lain seperti plastic dan logam karena harganya yang murah, mudah diperoleh dan penggunaannya yang luas. Selain sebagai kemasan, kertas juga berfungsi sebagai media komunikator dan media cetak. Kelemahan kemasan kertas untuk mengemas bahan pangan adalah sifatnya yang sensitive terhadap air dan mudah dipengaruhi oleh kelembaban udara lingkungan.

\section{b. Kemasan Kayu}

Kayu merupakan bahan pengemas tertua yang diketahui oleh manusia, dan secara tradisional digunakan untuk mengemas berbagai macam produk padat seperti barang antik dan emas, keramik, dan kain. Kayu adalah bahan baku dalam pembuatan palet, peti atau kotak kayu di negara-negara yang mempunyai sumber kayu alam dalam jumlah banyak. Tetapi saat ini penyediaan kayu untuk pembuatan kemasan juga banyak menimbulkan masalah karena makin langkahnya hutan penghasil kayu. Desain kemasan kayu tergantung pada sifat dan berat produk, kontruksi kemasan, bahan kemasan dan kekuatan kemasan, dimensi kemasan, metode dan kekuatan. Penggunaan kemasan kayu baik berupa peti, tong kayu atau palet sangat umum di dalam transportasi berbagai komoditas dalam perdagangan internasional. Pengiriman produk kerajinan seperti keramik sering di bungkus dengan peti kayu agar dapat melindungi keramik dari resiko pecah. 
Kemasan kayu umumnya digunakan sebagai kemasan tersier untuk melindungi kemasan lain yang ada di dalamnya.

\section{c. Kemasan Plastik}

Beberapa jenis kemasan plastic yang dikenal adalah polietilen, polipropilen, polyester, nilon dan vinil film. Jenis plastic yang banyak digunakan untuk berbagai tujuan $(60 \%$ dari penjualan plastic yang ada di bumi) kemasan adalah polistiren, Polopropilen, Polivinil Klorida, dan Akrilik.

\section{KESIMPULAN}

1. Kemasan berfungsi sebagai melindungi produk dalam perjalanan dari produsen ke konsumen.

2. Kemasan dapat meningkatkan laba perusahaan, tentu dengan membuat kemasan yang menarik dan berkualitas.

3. Kemasan suatu identitas yang lebih efektif, dengan sendirinya mencegah pertukaran oleh produk pesaing, karena kemasan merupakan satu-satunya cara perusahaan membedakan produknya.

4. Kemasan suatu komunikasi secara langsung secara otomatis dipahami dan suatu pikat secara langsung tanpa promosi tanpa menekan biaya dan waktu.

5. Kemasan suatu yang menimbulkan rasa senang yang menciptakan rasa simpati dan rasa tersendiri.

6. Kemasan merupakan satu solusi untuk menarik perhatian konsumen karena berhadap langsung dengan konsumen, seiring dengan perkembangan jaman dan meningkatnya persaingan.

7. Fungsinya kemasan yang dulunya hanya sebagai wadah atau pelindung, berubah menjadi alat jual yang menciptakan citra kepada produk yang di jual. 


\section{DAFTAR PUSTAKA}

Cangara, Hafied. 2012. Pengantar Ilmu Komunikasi. Jakarta: Raja Grafindo Persada Cenadi, Christine S. 1999. Elemen-Elemen dalam Dasar Komunikasi Visual. Jurnal Nirmala Vol.1 No.1 Universitas Kristen Petra Surabaya.

Cenadi, Christine Suharto, Peranan Desain Kemasan dalam Dunia Pemasaran. Jurnal Nirmala 2.1 (Januari 2000) : 92-103

Christy, Priscilla. 2014. Pengaruh Desain Kemasan (Packaging) pada Impulsive Buying. Yogyakarta: Universitas Atma Jaya

Gobe, Marc. 2005. Emotional Branding. Jakarta: Erlangga

Herudiyanto, Marleen S. 2008. Teknologi Pengemasan Pangan. Bandung: Widya Padjadjaran.

Iwan Wirya. 1999. Kemasan yang Menjual. Jakarta: PT. Gramedia Pustaka Utama.

Julianti. E. dan Nurminah. M. 2006. Teknologi Pengemasan. Departemen Teknologi Pertanian, Fakultas Pertanian. Universitas Sumatra.

Kartajaya, Hermawan. 1996. Marketing Plus 2000: Siasat Memenagkan Persaingan Global. Jakarta : Gramedia

Klimchuk, Marianne Rosner dan Krasovec, Sandra A. 2007. Desain Kemasan: Perencanaan Merek Produk yang Berhasil Mulai dari Konsep sampai Penjualan. Jakarta: Erlangga

Kotler, Philip. 1997. Dasar-Dasar Pemasaran. Jakarta: Prenhallindo.

M. A., Morissan. 2010. Periklanan: Komunikasi Pemasaran Terpadu. Jakarta: Ramdina Prakasa.

Muharam, Ashari Satrio. 2010. Analisis Pengaruh Desain Kemasan Produk dan Daya Tarik Iklan Terhadap Brand Awareness dan Dampaknya pada Minat Beli Konsumen. Semarang: Universitas Diponegoro.

Rosner, Klimchuk Marianne dan Sandra A. Krasovec. 2002. Desain Kemasan. Jakarta: Erlangga.

Sunyoto, Danang. 2013. Perilaku Konsumen: Panduan Riset Sederhana untuk Mengenali Konsumen. Yogyakarta: Caps Publishing.

Wirya, Iwan. Kemasan yang Menjual. Jakarta: PT. Gramedia Pustaka Utama. 1999. 